\title{
IR35 - where to now after the judicial review decision?
}

\author{
by Francesca Lagerberg ACA, Barrister
}

The author considers the fall-out from the case of $R_{v}$ Professional Contractors Group Ltd \& Others.

$\mathrm{O}$ n Monday 2 April the judgment was handed down in the judicial review case concerning the legality of the rules affecting the provision of personal service companies ('IR35'). The judge held that the case brought by the Professional Contractors Group (PCG) did not succeed and IR35 did not breach human rights or European law.

IR35 has been by far the most contentious addition to the UK tax system in recent years. Introduced primarily to target a perceived unfair avoidance of National Insurance Contributions (NICs) by the payment of dividends rather than salary, it sets up a new regime for those who provide personal services via an intermediary. For those affected, it requires the consideration of a hypothetical contract between the worker who provides personal services through an intermediary, such as a company or partnership, and the client with whom the intermediary has contracted. The issue is whether the worker is effectively an employee or self-employed in relation to the client. This involves the consideration of the Schedule D/Schedule E status cases that we have grown to know if not love.

Those who are determined to be 'employees' under this hypothetical contract must perform a deemed payment calculation, usually at the tax year end, and pay any tax and NICs due by the normal PAYE payment dates. This article considers what (if any) guidance we can draw from the judicial review decision.

\section{THE FACTS OF THE CASE}

The PCG and others contended in the case that the IR35 rules should be challenged on the basis that they were incompatible with European Community Law and the Human Rights Act 1998.

\section{Human Rights}

The human rights angle in the case always appeared to be a fallback argument. On the issue of whether IR35 breaches the Human Rights Act 1998, the High Court Judge, Mr Justice Burton, noted that:

'The legislation does not create a new category of law. It submits the service contractors to the same law as they would have been subject to, but for the interposition and/or operation of the service company'.
This is referring to the Schedule D/Schedule E test for determining if someone is self-employed or an employee. He did go on to criticise various aspects of the Revenue's guidance on employment status, such as the statement in the Revenue's Employment Status Manual that 'mutuality of obligation' is not a relevant issue in such cases. Mutuality of obligation means that if someone is offered work and feels obliged to take it, and the person offering it feels obliged to offer it to that person, there is evidence of a link between the two that might be indicative of an employment rather than self-employment arrangement. The issue of Revenue guidance is returned to below.

However, despite misgivings about some of the Revenue's guidance material on status issues the judge did not think this led to 'unacceptable uncertainty' and nor was IR35 incompatible with fundamental rights. Therefore it did not breach the Human Rights Act.

\section{European Law}

The European aspect was amended during the case to specifically seek a declaration that IR35 was an unnotified State aid contrary to Articles 87 and 88 of the EC Treaty. Did IR35 effectively amount to unlawful state aid because it helped those larger companies unaffected by IR3 5 who are, at least in certain sectors, competitors of the service companies? After careful consideration of the law on state aid, he concluded that:

'No one can be identified as a recipient of that aid, certainly no one sufficiently specifically identified or identifiable: and looking at it, ... on a broad pragmatic basis in the light of the policy underlying Article 87, this was not state aid, and consequently did not require to be notified'.

The second European law aspect was whether IR35 was an unlawful hindrance to free movement of workers, freedom of establishment and freedom to provide services, contrary to Articles 39, 43 and 49 respectively of the Treaty. No again, said the judge. He made a careful analysis of the facts but found nothing that warranted a finding of a breach in these areas.

The PCG had argued that IR35 would make workers, especially in the field of information technology, be put off from coming to this country to work and, even worse, driven 
to leave the UK because of the harsher regime. However, despite accepting that the rules in the UK affecting such workers were now more restrictive, the judge was not convinced that this was disproportionate in relation to the tax avoidance that the rules were brought in to combat.

The judge did make eight findings of fact in this case:

(1) The intent of IR35 is to eliminate the avoidance of tax and NIC on payments made by clients in respect of services provided by those who are in fact equivalent to employees; and it has that effect on the companies to which it applies.

(2) Many service contractors will be required to pay more monies and earlier to the Inland Revenue under IR35 than under the previous arrangements.

(3) At least two-thirds of service contractors are caught by the arguments advanced under the European law elements of the case.

(4) Instead of certainty as to the impact of tax and NIC, service contractors as a result of IR35 have uncertainty as to whether IR35 will or will not apply to a particular engagement.

(5) In respect of engagements or contracts sought, or services to be provided, by service contractors, there is or would be competition with companies who would be unaffected by IR35.

(6) Companies unaffected by IR35 will have greater flexibility to arrange their tax affairs, to allocate tax between income tax and corporation tax, to defer tax liabilities, and to pay lesser salaries to those providing the services and higher dividends to shareholders, than service contractors.

(7) Some service contractors may not continue to operate in the UK as a result of IR35, and some who have intended to come to the UK to set up or work as service contractors may not now come to the UK.

(8) Factors 5, 6 and/or 7 above may have an effect on trade between Member States.

\section{WHAT HAPPENS NOW?}

The end result in this case was rather bluntly summarised by the victorious Inland Revenue in a press release on 2 April 2001. It noted:

'The IR3 5 legislation is the law of the land, as enacted by Parliament and upheld by the Court. Individuals affected by it will need to make sure they take the necessary actions to ensure they comply with their obligations under this law'.

\section{WHAT DOES THE CASE REALLY MEAN?}

The key point arising out of the case appears to be that little has changed. Those that were clearly within IR35 before the case will be so now. Those that were outside will remain outside.
What is likely to result from the case is that the Revenue may revisit some of its guidance. It has stated that it will 'look at the judge's remarks to see if there are any amendments that need to be made to clarify any of the wording'. This may result in more clarity for those who are in the borderline situation of being unsure of whether they are within or outside of IR35. It is also important for those assessing the Revenue's guidance material to be aware that this guidance is only the Revenue's interpretation and should be viewed in that light. If you think the situation warrants it, its view can be challenged and various aspects of the judicial review case highlight where the weak spots may be.

\section{HOW WILL PEOPLE KNOW IF THEY CAUGHT BY IR35?}

Whilst some fall squarely outside the rules, others are clearly within them. But of course there are large areas of 'grey' where the issue may not be clear.

Firstly, you need to determine if someone is working through an intermediary, which is caught by IR35. The rules here can be found in the Finance Act 2000, Sched. 12. If the intermediary is caught, then it is necessary to imagine that if the intermediary was taken out of the picture and a notional or hypothetical contract placed between the worker and the client, would that contract be one of employment or self-employment?

As the test is whether or not the worker is effectively employed, you need to apply the traditional Schedule $\mathrm{D} /$ Schedule $\mathrm{E}$ tests. There is a considerable body of case law in this area (see Hall $v$ Lorimer [1994] STC 23, for instance) and the issue all comes down to the facts. The over-all picture is the key factor and whatever the contract says the reality of the situation takes precedence.

Important factors will include:

- Is the worker at financial risk in the project? Can he make losses as well as profits?

- Can he make more money if he does the job well?

- Can he hire his own workers or provide substitutes for the job instead of himself?

- Can he control his work? This can encompass where he works, when he works, what he does and how he does it.

- The intention of the parties.

- The length of the contract.

- The pay structure, e.g. holiday pay.

- The number of engagements the worker has.

However, it is important to look at the 'big picture' and not take a 'check-list' approach.

\section{WHAT DOES THE JUDICIAL REVIEW CASE ADD TO THE STATUS DECISION?}

Some very useful points in relation to employment status were mentioned in the IR35 judicial review case. These were in particular: 
(1) Mr Justice Burton noted that there is a 'heavy responsibility' upon the tax inspector in respect of the position of any individual taxpayer. He confirmed that: 'It is essential that there is a sensitive and co-operative approach taken by such Inspectors and that the Revenue guidance is clear and helpful'.

(2) He then went on to criticise various aspects of the guidance offered by the Revenue in its Employment Status Manual (ESM). As mentioned, above he criticised the Revenue's unwillingness to accept the importance of 'mutuality of obligation' in determining someone's employment status.

The judge also criticised the Revenue's attitude in the Manual to 'substitution clauses'. This is the right of a worker to send someone along, of equal competence as himself or herself, to perform services and has been found by the courts to be a strong indicator of self-employment (e.g. Express and Echo Publication v Tanton [1999] ICR 693). The importance of the right of substitution is very watered down in the ESM. The judge noted, in particular:

'It would not be right to make an absolute statement, as the Revenue appears to do in another of its guidance documents, that the need to obtain a client's permission necessarily negates the existence of a right of substitution and/or points to employment'.

The judge also states quite explicitly that it is:

.essential to any consideration of the common law test as to whether an individual is trading as an employee or as an independent contractor, that consideration should be given to whether he is in business on his own account'.

This comment highlights that it is important to consider this issue before looking at any surrounding contracts.

There has been considerable discussion as to the relevance of various contracts surrounding a possible IR35 arrangement. For example, is a contract between agencies that an intermediary works with, relevant to the employment status of a particular worker? The judge notes the following:

'It appears to me clear that the Revenue must bear in mind that under IR35 they are not considering an actual contract between the service company and the client, but imagining or constructing a notional contract which does not in fact exist. In those circumstances, of course the terms of a contract between the agency and the client as a result of which the service contractor will be present at the site are important, as would be the terms of any contract between the service company and the agency. But particularly given the fact that, at any rate at present, a contract on standard terms may or may not be imposed by an agency, or may be applicable not by reference to a particular assignment, but on an on-going basis, and may actually bear no relationship to the (non-contractual) interface between the client and the service contractor, such documents can only form a part, albeit obviously an important part, of the picture'.

The Revenue will give an opinion on whether an existing contract (not a future contract) falls in or outside of the rules.

\section{WHAT IS I MADE THE WRONG STATUS CASE DECISION?}

Clearly the issue of someone's work status can be complex. It is important to consider all available guidance and to set out the complete situation to those you are advising explaining the implications of any decision.

There are two relevant points in the judicial review case on this issue:

(1) In an Inland Revenue penalty statement issued on 13 March 2001, it states that although penalties may be sought for an incorrect return (under the normal PAYE rules) an

'...employer might fail to meet its obligations to file a correct return because of a genuine misunderstanding about the rules caused by their newness. This would be taken into account, along with the effort made by the employer to establish whether a contract is subject to the new rules, when considering penalties'

(2) There is also reference to the Revenue's leaflet IR109 that expressly states: 'if you have taken all reasonable care, we do not seek penalties'.

Of course, the latter point begs the question of what is 'reasonable'. Tax advisers would be wise to make a clear file note of what factors they took into account in reaching their decisions on status issues.

\section{DOES IR35 GIVE EMPLOYMENT RIGHTS TO AFFECTED WORKERS?}

It was impishly suggested by the Judge during the judicial review case that if a worker was within IR35 they might contend that they were entitled to some of the benefits as well as the downsides of employment.

$\mathrm{Mr}$ Justice Burton dealt with this point in his judgment by saying that there is no binding conclusion that because someone is treated as an employee for tax purposes that they are an employee for any other purpose - although that would not preclude someone from arguing the point in relevant circumstances.

Being within IR35 does not grant entitlement as against a client as to the benefits of employment but insofar as NICs are paid on higher notional remuneration he will receive the benefit of those higher payments in respect of state benefits, which depend upon a person's NIC contribution history.

\section{WHAT HAPPENS IF THE DECISION IS APPEALED?}

The PCG, who brought the judicial review case, are still deciding if they will appeal. If they do, and are able to take an appeal, it is likely to involve a referral to the European Court of Justice on a question of law.

Francesca Lagerberg ACA, Barrister

Francesca Lagerberg is the Senior Technical Manager to the Tax Faculty of the Institute of Chartered Accountants in England and Wales. 